\title{
Antibody responses to tetanus toxoid in patients with primary biliary cirrhosis
}

\author{
D WATMOUGH, M A H FRENCH, ${ }^{*}$ D R TRIGER \\ From the Academic Departments of Medicine at the Royal Hallamshire and *Northern General Hospitals, \\ Sheffield
}

SUMMARY The primary and secondary antibody responses to tetanus toxoid were measured in 18 patients with primary biliary cirrhosis and compared with those in age and sex matched controls. Although the primary antibody response in the two groups was similar, the secondary IgM antibody response in primary biliary cirrhosis was significantly higher than that in control subjects. There seems to be a correlation between secondary IgM antibody titre and total serum IgM concentration, although this fails to reach significance $(\mathrm{p}=0.069)$. These results show that in primary biliary cirrhosis there is a failure to switch from IgM to IgG antibody synthesis in response to foreign antigens, and this may account for the increased serum IgM concentrations that are usually found in this disease.

\begin{abstract}
Although the aetiology of primary biliary cirrhosis is unknown, various immunological abnormalities are associated with the disease. As well as changes in regulatory $\mathrm{T}$ cell function, there is also a hyperactive humoral immune response-increases in total serum immunoglobulins and the presence of circulating auto antibodies-and increased concentrations of IgM in serum are found in over $80 \%$ of patients. This may represent an excessive IgM antibody response to exogenous antigens, which has also been postulated as the cause of the hyperglobulinaemia in liver disease. ${ }^{1}$ We investigated the antibody response to tetanus toxoid in patients with primary biliary cirrhosis to test this hypothesis.
\end{abstract}

\section{Material and methods}

We studied 18 women with a mean age of 60.9 years, (range 40-82) with primary biliary cirrhosis and no previous history of tetanus immunisation. Seven patients had early (histological stages I and II) and 11 had advanced (stages III and IV) disease. All patients had serum antimitochondrial antibody titres of greater than $1 / 80$, and consistent clinical, biochemical, and histological features of primary biliary cirrhosis. Seven patients were taking D-penicillamine in doses ranging from 250 to $875 \mathrm{mg}$ a day at the time

Accepted for publication 21 January 1987 of the study; no other anti-inflammatory or immunosuppressive drugs were being taken.

Seventeen women with a mean age of 57.4 years (range 36-77) attended the accident and emergency department with minor lacerations, who required tetanus toxoid as part of their treatment, acted as controls. The control group had no history of liver disease or any other systemic disorder and had not had previous tetanus toxoid immunisation. None was taking drugs regularly.

All patients and controls gave written informed consent; the project was approved by the local Ethical Committee.

Immunisation was by an intramuscular injection of $0.5 \mathrm{ml}$ adsorbed tetanus toxoid BP (Wellcome Foundation Ltd, London, England) containing $40 \mathrm{IU}$ of toxoid, and a second dose was given two months later. The time between primary and secondary antigenic challenge was the same for both groups.

Blood was taken before the first immunisation to check for tetanus toxoid antibody, and also two weeks after each inoculation to measure the primary and secondary antibody responses. Serum was separated and stored at $-20^{\circ} \mathrm{C}$ until testing was carried out on coded samples. Tetanus toxoid antibody titres were measured using an enzyme linked immunosorbent assay ${ }^{2}$ with the addition of goat antihuman IgG or IgM alkaline phosphatase conjugate (Sigma Chemicals, Poole, Dorset, England) as second antibodies, and a different preparation of human anti- 
Table 1 Immunological data on patients and controls

\begin{tabular}{|c|c|c|}
\hline & $\begin{array}{l}\text { Patients with } \\
\text { primary biliary } \\
\text { cirrhosis } \\
(n=18)\end{array}$ & $\begin{array}{l}\text { Controls } \\
(n=17)\end{array}$ \\
\hline Serum IgG (g/l) Mean (SEM) & $14 \cdot 3 \quad(1 \cdot 3)$ & $13.9(0.6)$ \\
\hline $\begin{array}{l}\text { Serum } \operatorname{IgM}(g / l) \text { Mean (SEM) } \\
\text { Serum IgA }(g / l) \text { Mean }(\text { SEM })\end{array}$ & $\begin{array}{ll}5 \cdot 8 & (1 \cdot 0)^{*} \\
3 \cdot 1 & (0 \cdot 6)\end{array}$ & $\begin{array}{l}1 \cdot 3(0 \cdot 1) \\
2 \cdot 4(0 \cdot 2)\end{array}$ \\
\hline $\begin{array}{l}\text { Primary tetanus toxoid antibod } \\
\text { IgG response (units) } \\
\text { Mean (SEM) }\end{array}$ & $27 \cdot 0 \quad(9 \cdot 3)$ & $18 \cdot 0(4 \cdot 1)$ \\
\hline $\begin{array}{l}\text { Secondary tetanus toxoid antib } \\
\text { IgG response (units) } \\
\text { Mean (SEM) }\end{array}$ & $81 \cdot 7(21 \cdot 2)$ & $50.5(6.4)$ \\
\hline $\begin{array}{l}\text { Primary tetanus toxoid antibod } \\
\text { IgM response (units) } \\
\text { Mean (SEM) }\end{array}$ & $25 \cdot 1 \quad(2 \cdot 7)$ & $24 \cdot 4(3 \cdot 5)$ \\
\hline $\begin{array}{l}\text { Secondary tetanus toxoid antib } \\
\text { IgM response (units) } \\
\text { Mean (SEM) }\end{array}$ & $19 \cdot 1 \quad(2 \cdot 4) \dagger$ & $11 \cdot 4(2 \cdot 6)$ \\
\hline
\end{tabular}

${ }^{*} \mathrm{p}<0.001$ and $+\mathrm{p}<0.01 v$ controls.

tetanus immunoglobulin (Batch GT14, Blood Products Laboratory, Elstree, England) as a calibrant. Antibody titres in test sera were calculated in arbitrary units using the calibrant. Serum immunoglobulins were measured using a turbidimetric technique on samples taken immediately before immunisation.

The Mann-Whitney U test and Spearman's rank correlation used were for analysing the differences

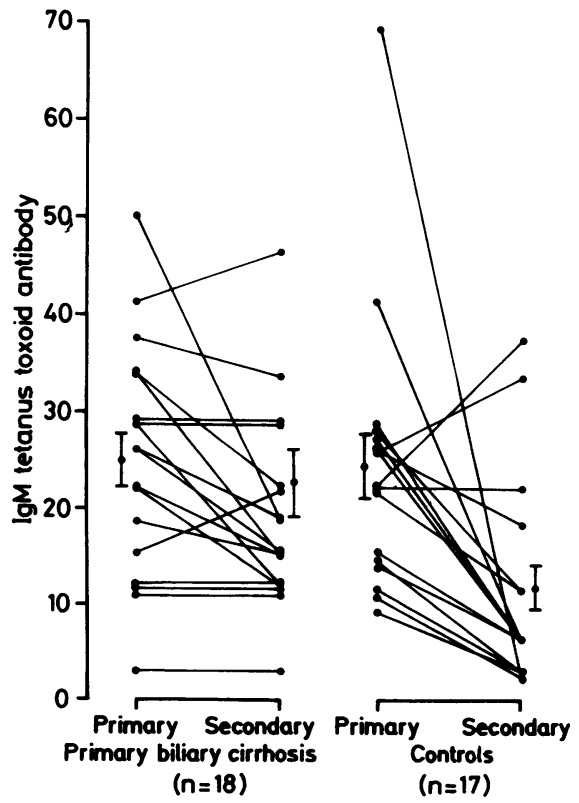

Fig I Primary and secondary IgM tetanus toxoid antibody responses in patients and controls.

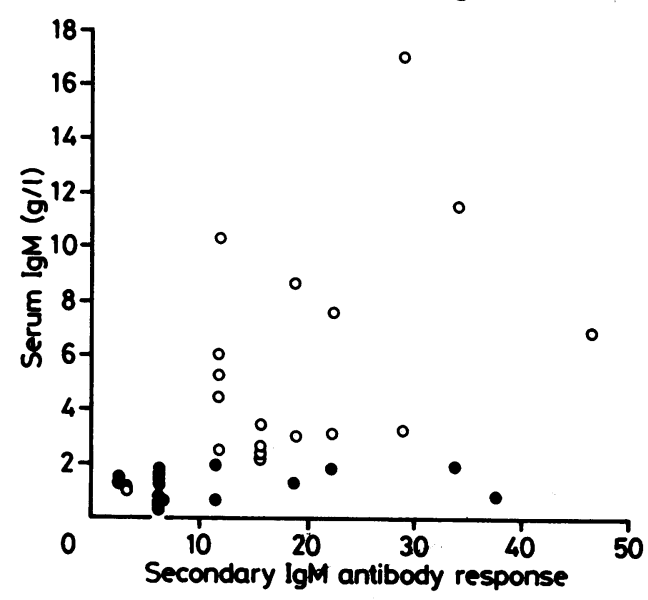

Fig 2 Correlation of serum IgM titre and secondary IgM antibody response to tetanus toxoid: 0 patients with primary biliary cirrhosis; $\bullet$ controls.

between groups, and data were assumed to be nonparametric in distribution.

\section{Results}

No IgM or IgG antibodies were detectable in any patient before immunisation. The amounts of IgM antibody produced in both primary and secondary responses were similar in patients and controls (table 1). There was also no difference between primary IgM antibody production in the two groups, but the secondary IgM antibody response was significantly greater in those with primary biliary cirrhosis $(p<0.01)$. The mean IgM antibody titre in patients with primary biliary cirrhosis after the second immunisation was similar to that after the first, but in the control group it was significantly lower $(p<0.01)(f i g 1)$. This was because the titre of IgM tetanus toxoid antibody found after secondary immunisation was either more than, or the same as, that after the primary response in eight of 18 patients and only three of 17 controls.

The results in the control group were not affected by those of one subject with an abnormally high primary antibody response of 69.4 units, followed by an abnormally low secondary response $2 \cdot 50$ units. Exclusion of this subject resulted in mean primary and secondary responses of 20.3 and 12.4 units, respectively. The difference between antibody response in controls and patients with primary biliary cirrhosis remained significant.

Although there seemed to be a correlation between total serum IgM titre and secondary IgM toxoid antibody titre (fig 2$)$, it did not reach significance $(p=$ 0.069 ) either between the two groups or among the 
Table 2 Effect of D-penicillamine on antibody responses to tetanus toxoid in primary biliary cirrhosis

\begin{tabular}{lll}
\hline & $\begin{array}{l}\text { Patients taking } \\
D-\text { penicillamine } \\
(n=7)\end{array}$ & $\begin{array}{l}\text { Patients not taking } \\
\text { D-penicillamine } \\
(n=11)\end{array}$ \\
\hline $\begin{array}{l}\text { Response } \\
\begin{array}{l}\text { Primary IgM antibody } \\
\text { (units) }\end{array}\end{array}$ & $19 \cdot 40$ & $28 \cdot 80$ \\
$\begin{array}{l}\text { Secondary IgM antibody } \\
\text { (units) }\end{array}$ & 14.59 & 21.92 \\
$\begin{array}{l}\text { Primary:secondary IgM } \\
\text { antibody ratio }\end{array}$ & $1 \cdot 33: 1$ & $1 \cdot 31: 1$ \\
$\begin{array}{l}\text { Primary IgG antibody } \\
\text { (units) }\end{array}$ & 20.60 & $31 \cdot 10$ \\
$\begin{array}{c}\text { Secondary IgG antibody } \\
\text { (units) }\end{array}$ & 72.20 & 87.70 \\
\hline
\end{tabular}

patients with primary biliary cirrhosis alone. There was no correlation between secondary IgM toxoid antibody response and serum IgM, IgG primary, or secondary toxoid antibody response, or primary $\operatorname{IgM}$ toxoid antibody response. Although the secondary IgG toxoid antibody response in patients with primary biliary cirrhosis was higher than in control subjects, the difference was not significant $(p>0 \cdot 1)$.

The mean serum IgM titres in (stages I and II) primary biliary cirrhosis were not significantly different from those in stages III and IV. Similarly, there was no difference between the primary and secondary IgM tetanus toxoid antibody titres in early, compared with advanced, liver disease: primary IgM titres $24 \cdot 6$ (stages I and II) $v 25.1$ units (stages III and IV); secondary IgM titres $19 \cdot 2$ (stages I and II) $v 19.0$ units (stages III and IV). Both primary and secondary IgM and IgG antibody responses to tetanus toxoid were reduced in patients receiving D-penicillamine (table 2) but none of these differences was significant. Penicillamine does not, however, have any effect on the ratio of primary to secondary IgM antibody response and so does not influence the IgM to IgG conversion.

\section{Discussion}

We have shown that although the primary IgM antibody response to tetanus toxoid in patients with primary biliary cirrhosis is normal, there is significantly more IgM specific antibody production following a secondary antigenic challenge compared with that seen in a group of age and sex matched control subjects.

This is the first study that we know of which shows excessive IgM antibody responses to a specific antigen in patients with primary biliary cirrhosis. In the only other study of specific antibody responses in primary biliary. cirrhosis Thomas $e t \mathrm{al}^{3}$ reported a decreased secondary response to bacteriophage $ø \mathrm{X} 174$, which they interpreted as being due to a reduction of specific IgG antibody production. They measured the immunoglobulin class of antibody produced during the secondary response, and not after primary immunisation, so it is not possible to draw any conclusions about IgM/IgG conversion in response to $₫ X 174$.

Our observations support the hypothesis that there is a defect in suppressor $\mathrm{T}$ cell production as a result of which the liver fails to change from IgM to IgG antibody synthesis despite repeated antigenic challenges. There seems to be a correlation between secondary tetanus toxoid, specific IgM antibody titres, and total serum IgM which suggests, but does not prove, that our results may apply to a wide range of exogenous antigens, and goes some way towards explaining the high IgM titres found in primary biliary cirrhosis. James et $a^{4}$ recently published evidence that suggested that only a small proportion of B cells in patients with primary biliary cirrhosis are hyperactive, and that these cells are responsible for the humoral abnormalities. Our results do not exclude this possibility, but suggest an additional mechanism, while Nouri-Aria et al, on the basis of in vitro studies, suggested that at least two different suppressor subpopulations may be responsible for regulating IgM production. $^{5}$

Although there are ethical benefits to be gained from using an antigen such as tetanus toxoid that is both safe and effective, its already widespread use means that it is difficult to be certain that the responses measured were truly primary and secondary. Despite the fact that all patients included in this study were carefully questioned about previous immunisation against tetanus, we cannot exclude completely the possibility that they may have received toxoid a long time ago, particularly as most subjects were in late middle age. No antibody of either class was detectable in any serum sample prior to immunisation, but this does not exclude previous immunisation as we were also unable to detect circulating antibody in seven other patients (four controls and three with primary biliary cirrhosis) who admitted to immunisation more than five years earlier. The IgM antibody response to a single dose of toxoid in these seven patients, however, was substantially higher than that seen in the study patients (204.2 units, range $18-425, v$ patients with primary biliary cirrhosis 27.0 units, and controls 18.0 units), thus supporting the hypothesis that true primary and secondary response were being measured in the latter group. Furthermore, it would be difficult to explain the quantitative difference in antibody response between patients with primary biliary cirrhosis and controls as being due to previous immunisation. The pattern of IgM and IgG antibody production seen in the control subjects was 
entirely consistent with exposure to a new antigen, and contrasts with that observed in the group with primary biliary cirrhosis.

Because the serum IgM titre and the tetanus toxoid antibody response are independent of the severity of the liver disease, there is nothing to suggest that they arise as a consequence of the liver damage. We found no evidence to suggest that they have a direct role in the pathogenesis of liver disorders.

\section{References}

1 Triger DR, Wright R. Hyperglobulinaemia in liver disease. Lancet 1973;i:1494-6.

2 French MAH, Harrison G. Systemic antibody deficiency in patients without immunoglobulin deficiency or with selective IgA deficiency. Clin Exp Immunol 1984;56:18-21.

3 Thomas HC, Holden R, Jones JV, Peacock DB. Immune response to $ø \mathrm{X} 174$ in man. 5. Primary and secondary antibody production in primary biliary cirrhosis. Gut 1976;17:844-8.

4 James SP, Jones EA, Hoofnagle JH, Strober W. Circulating activated B cells in primary biliary cirrhosis. J Clin Immunol 1985;5:254-60.

5 Nouri-Aria KT, Hegarty JE, Neuberger J, Eddleston ALWF, Williams $R$. In vitro studies of the mechanism of increased serum IgM levels in primary biliary cirrhosis. Clin Exp Immunol 1985;61:297-304.

Requests for reprints to: Dr DR Triger, Department of Medicine, Royal Hallamshire Hospital, Sheffield S10 2JF, England. 